\title{
A new species of Hallucigenia from the Cambrian Stage 4 Wulongqing Formation of Yunnan (South China) and the structure of sclerites in lobopodians
}

\author{
Michael SteineR, ShiXUE HU, JIANNI LIU \& HELMUt KeUPP
}

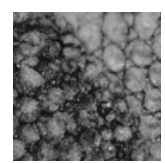

\begin{abstract}
Hallucigenia hongmeia sp. nov. and Hallucigenia sparsa are described from the Cambrian Stage 4 Guanshan fossil Lagerstätte of Wulongqing Formation from Guangwei in Kunming district, Yunnan Province, South China. The paired trunk sclerites of lobopodians reveal a general net-like microstructure, which is documented for the genera Hallucigenia, Onychodictyon and Microdictyon. This microstructure is comparable to a similar microstructure in paired trunk sclerites of the palaeoscolecidan sensu lato Cricocosmia and Tabelliscolex. The net-like trunk sclerites of lobopodians are interpreted as having carried numerous sensory or secretory papillae. Lobopodian sclerites such as Hallucigenia, Onychodictyon and Microdictyon and the palaeoscolecidans s.l. Cricocosmia and Tabellicsolex were primarily composed of tanned organic structures. Duplicates of trunk sclerites in Microdictyon and Cricocosmia point to a moulting of the external cuticle. The structure and form of prominent claws in Hallucigenia hongmeia sp. nov. are interpreted as indicative of an adapted lifestyle in the epibenthos. - Key words: Cambrian, lobopodians, Hallucigenia, Guanshan, fossil Lagerstätte, sclerites.
\end{abstract}

Steiner, M., Hu, S.X., LiU, J. \& KeupP, H. 2012. A new species of Hallucigenia from the Cambrian Stage 4 Wulongqing Formation of Yunnan (South China) and the structure of sclerites in lobopodians. Bulletin of Geosciences 87(1), 107-124 (11 figures, 2 tables). Czech Geological Survey, Prague. ISSN 1214-1119. Manuscript received April 18, 2011; accepted in revised form October 6, 2011; published online February 2, 2012; issued February 29, 2012.

\begin{abstract}
Michael Steiner, Jianni Liu \& Helmut Keupp, Freie Universität Berlin, Department of Earth Sciences, Malteserstrasse 74-100, Haus D, D-12249 Berlin, Germany, Michael.Steiner@FU-Berlin.de•Shixue Hu, Chengdu Institute of Geology and Mineral Resources, No. 2, N-3 Section, First Ring Road, Chengdu 610081, Sichuan Province, P.R. China, hushixue@hotmail.com•Jianni Liu, Early Life Institute, The Key Laboratory of Continental Dynamics, Northwest University,Xi'an, 710069, PRChina, liujianni@126.com
\end{abstract}

Lobopodians represent a typical Palaeozoic group of panarthropodan organisms, which have so far only been reported from Cambrian to Silurian marine sediments and Carboniferous paralic environments, indicating that this metazoan clade underwent severe transitions in bauplans, metabolism, and ecological adaptions during the late Palaeozoic. The highest diversity of the lobopodians is known from the Cambrian Stage 3 where it peaks out in the Chengjiang-type fossil Lagerstätten of Yunnan Province (China) with the occurrence of 13 species and 11 genera in soft-tissue preservation. It is remarkable that this great diversity peak for lobopodians also coincides with the first appearance of this group within the Cambrian Stage 3. This might be interpreted as supporting the idea of an explosive radiation of metazoan clades within the earliest Cambrian, creating the highest diversity in bauplans in metazoans and specific metazoan clades, which were affected by only minor changes, adaptions, but underwent major selection by extinctions in the later Earth history (Gould 1989).
According to previous studies, the major increase in metazoan diversity occurred during Cambrian Stage 3 to 4 (Atdabanian to Botoman in terms of Siberian regional stages and Qiongzhusian in terms of Chinese regional stages; Li et al. 2007, Zhuravlev 2001). This is mostly due to rapid diversification in the Archaeocyatha and Ecdysozoa - all forms that developed biomineralized or tanned organic skeletons. The major increase in metazoan diversity during this phase of radiation was partly due to rapid speciation in ecdysozoan clades, such as arthropods, priapulids, lobopodians, and deuterostome clades, such as echinoderms. In contrast to the strong diversity radiation during Cambrian Stage 3-4, the major radiation in metazoan disparity (number of different major bauplans) occurred earlier during the Terreneuvian. However, for long time it was uncertain whether ecdysozoan bauplans were among those developed during this explosive phase of metazoan radiation. In a recent comparison between the traditional skeletal fossil record, soft-tissued Burgess Shale-type fossils, and 


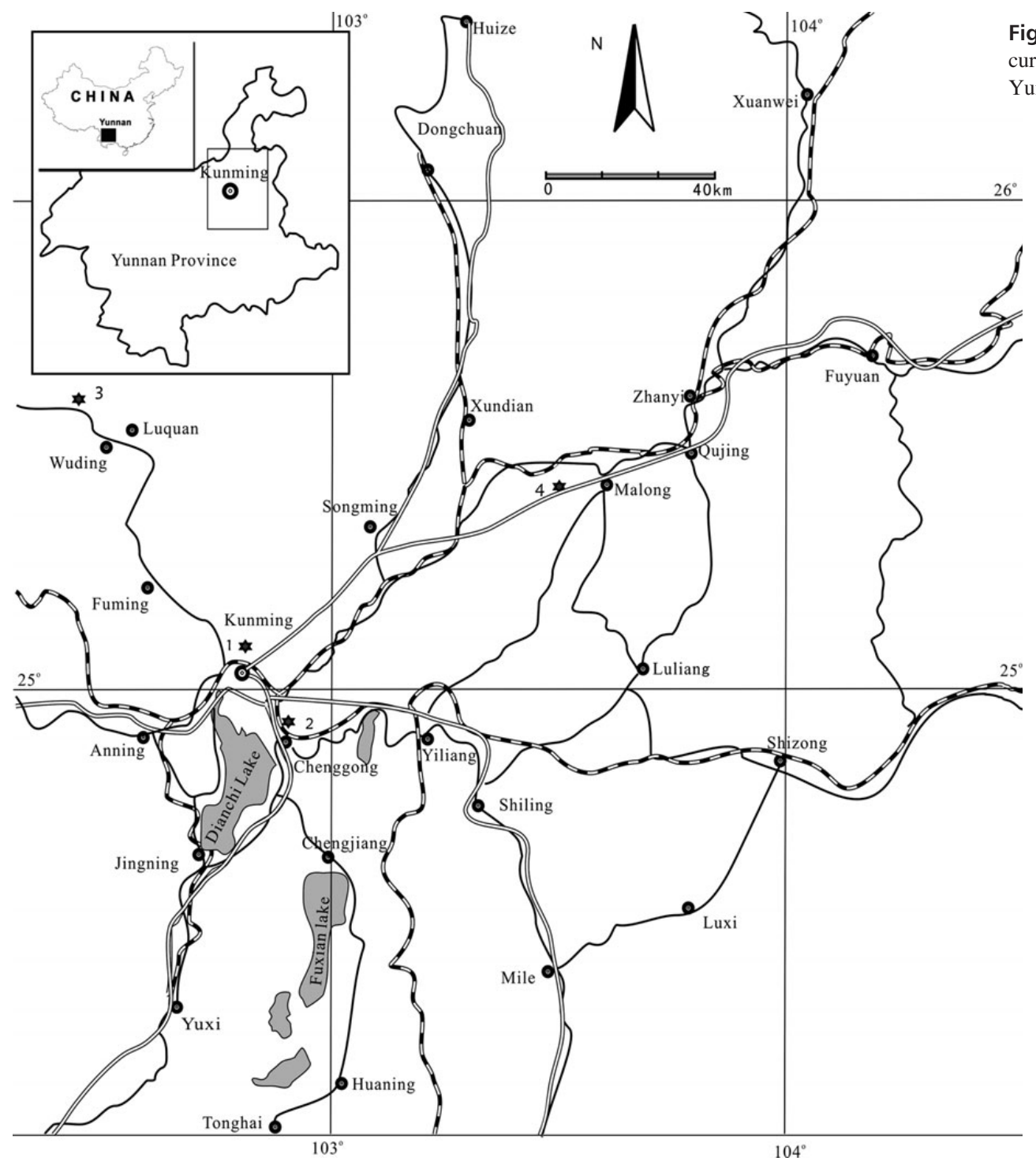

Figure 1. Location map for the occurrence of Guanshan Fauna in SE Yunnan, China.

- Cities

* Fossil Localities

1: Gangtoucun

2: Guangwe

(Shitangshan)

3: Sapushan

4: Wulongqing phosphatized Orsten-type fossils, it has been shown that the apparent lack of ecdysozoan-grade remains from Terreneuvian sediments is most probably a preservational artefact (Steiner et al. 2010). An embryo with nascent cap-shaped sclerites similar to those occurring in the lobopodian Onychodictyon has been reported from the Fortunian of South China (Steiner et al. 2004).

Although first fossil lobopodians from the Carboniferous were described more than a century ago (Scudder 1890) and other celebrated Cambrian lobopodians such as Aysheaia pedunculata, Hallucigenia sparsa, and Xenusion auerswaldae were found and documented early in the last century (Walcott 1911, Pompeckj 1927 - but note that Xenusion had already been discovered before the First World War and was curated in a regional museum by Canoness v. Auerswald for about a decade before its formal description), there still exists a degree of uncertainty in the interpretation of the bauplans in specific lobopodians (e.g. concerning the anterior-posterior orientation, number of limbs, presence of antennae and specific sclerites) and the phylogenetic positions of species. The genus Hallucigenia represents one of the iconic fossils of the Burgess Shale, and its description and discussion in the pioneering study by Conway Morris (1977) contributed much to the understanding of lobopodians in general. The subsequent discovery of a new species of Hallucigenia in the Cambrian Stage 3 Chengjiang fossil Lagerstätte (Hou \& Bergström 1995) extended the occurrence of the genus into the range of the explosive radiation of metazoans. One individual from the Cambrian Stage 5 Kaili Biota has questionably been assigned to the genus Hallucigenia; however, this placement requires further confirmation (Zhao et al. 1999). New finds of remains resembling Hallucigenia from the Lower Ordovician Fezouata Fauna of Morocco (Van Roy et al. 2010) possibly indicate that the genus may have existed over a considerable range of time. 
The aim of the present study is to describe new finds of Hallucigenia from the less known Cambrian Stage 4 Guanshan biota and to discuss the structure and function of some lobopodian sclerites.

\section{Geology, material and methods}

The herein described new material of Hallucigenia was collected from the lower part of Wulongqing Formation at Shitangshan Quarry, Gaoloufang, Guangwei town of Kunming District (Fig. 1). Most soft-tissued or lightly sclerotized Burgess Shale-type fossils (including Hallucigenia) of this stratigraphic interval occur in the lower part of Wulongqing Fm. within the Palaeolenus Zone (Fig. 2) of the Cambrian Stage 4 (Canglangpuan regional stage).

Burgess Shale-type faunas also occur in the middle and upper parts of the Wulongqing Fm.; however, no Hallucigenia has yet been discovered from these stratigraphical levels. All Burgess Shale-type faunas of Wulongqing Fm. are designated as Guanshan fauna (Luo et al. 1999, 2008). It has been described across a wide area of SE Yunnan, mostly from the Kunming, Wuding, Huize, and MalongYiliang regions (Luo et al. 1999, 2008; Liu et al. 2012 this volume). An overview of the accompanying fauna has been given by Luo et al. (2008) and Hu et al. (2010).

The Wulongqing Formation comprises a thick sedimentary sequence dominated by mud- and siltstones, with few sandstone beds overlying a basal, well-sorted, transgressional conglomerate. The upper part of Wulongqing Fm. is dominated by coarser sediments, probably indicating a shallowing of the sequence. The lower part of Wulongqing Formation mostly consists of numerous fine mudstone beds with coarser, mostly sandy to silty erosional bases. Sediment marks, common bioturbation structures and the presence of wrinkled microbial mats indicate a shallow, well-oxygenated depositional setting, with a water depth of probably less than $50 \mathrm{~m}$. It is remarkable that soft-tissued remains like those of Hallucigenia co-occur with shell concentrations and bioturbation within the same beds. It is therefore evident that anoxia are not essential for soft-tissue preservation; however, in addition to anoxic settings that may enhance fossilization potential, a rapid deposition of fine clay mud may be sufficient to preserve delicate tissues. Moreover, it appears that the depositional rate within the Wulongqing Formation was high enough to enable part of the soft-tissued carcasses to undergo early diagenetic fossilization processes even though bioturbation was generally high.

The Chengjiang-type fossil material used for comparison is all from the Jiangshan, Mafang, Yulongsi, and Ercai/ Haikou outcrops of Cambrian Stage 3 Yuanshan Formation, Yunnan Province, China. Unless otherwise stated, all described material is housed at Yunnan Geological Survey in Kunming.

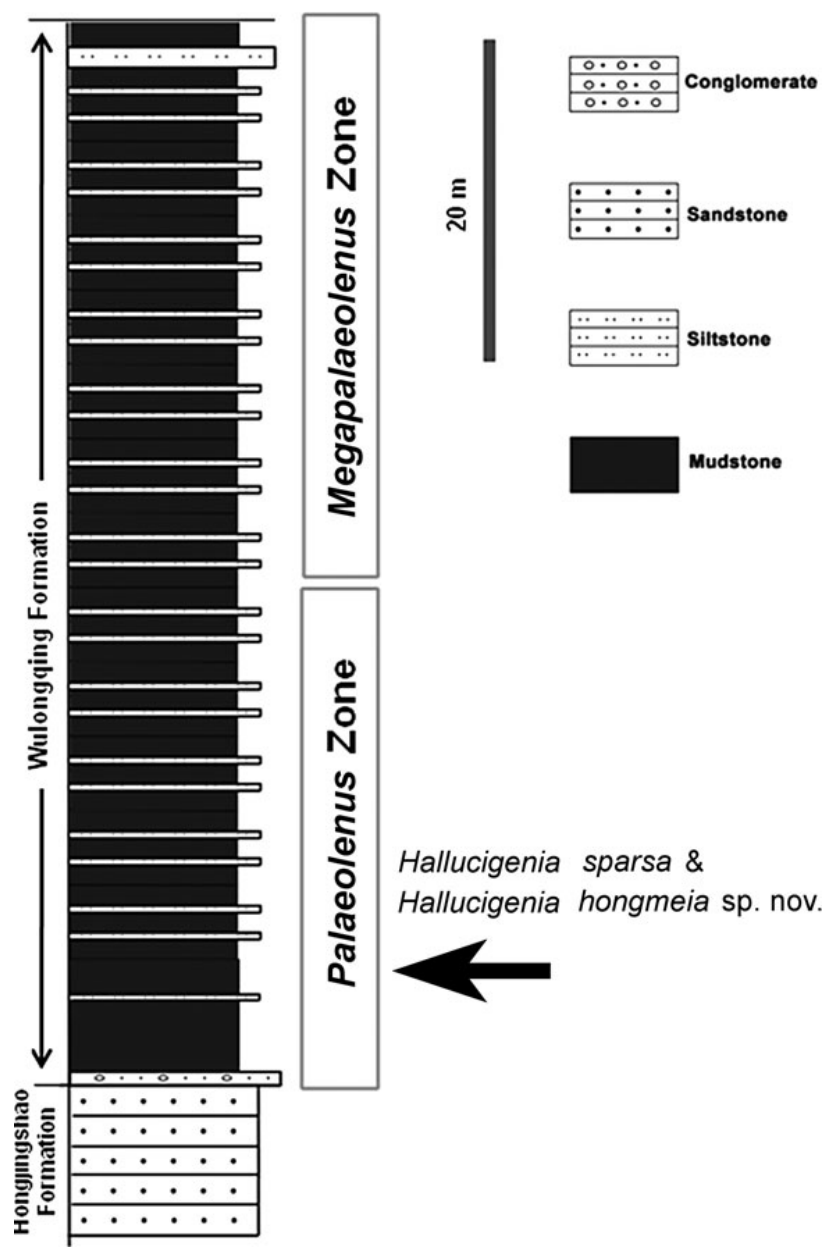

Figure 2. Simplified stratigraphic column of Wulongqing Fm. at Shitangshan, Yunnan (China); arrow indicates the level yielding Hallucigenia.

Part of the material was studied uncoated in an ordinary scanning electron microscope (SEM; HITACHI S2700) or an environmental SEM (ZEISS Supra $40 \mathrm{VP}$ ) using the secondary electron and backscatter electron mode at Technische Universität Berlin and Freie Universität Berlin, respectively. Elemental mapping and point analyses were carried out at the ZEISS Supra 40 VP SEM with an EDX $50 \mathrm{~mm}^{2} \mathrm{X}$-Max detector with Moxtex polycarbonate window of Oxford Instruments and INCA software. Carbon mapping was carried out at $10 \mathrm{kV}$, whereas other elements were mapped at $20 \mathrm{kV}$. Light microscopy was carried out using a digital DHS MicroCam 3.3 (3.3 Mega Pixel) attached to a LEICA MZ75 stereomicroscope.

\section{Systematic palaeontology}

The higher systematics of the so-called lobopodians is currently in a fluid state and requires further revision. This is mostly due to the fact that a number of new taxa have been 
described during the past decade, proving that the Lobopodia are not a monophyletic group (Budd 1999; Liu et al. 2007, 2011). In the most recent phylogenetic analysis of most lobopodians, lobopodian-like animals and anomalocaridids (Liu et al. 2011), it was shown that lobopodian-like organisms fall into two major clades. One of them, including Jianshanopodia and Megadictyon, is related to the anomalocaridids and indicates a closer relationship to the Arthropoda. This relationship is currently best illuminated by the newly described lobopodian-like genus Diania, which shows jointed arthropod-like limbs and a high grade of sclerotization, whereas other characters are rather lobopodian-like. The other major clade of lobopodians, including the herein discussed genera Hallucigenia, Onychodictyon and Microdictyon, are more closely allied with the modern Onychophora.

The new lobopodian Antennacanthopodia gracilis with antennae, ocelli, and walking pads at the limbs (Ou et al. 2011) reveals a close relationship with modern Onychophora and also argues against the classical subdivision of lobopodians into the clades of fossil Xenusia and the modern Onchophora (Dzik \& Krumbiegel 1989). Moreover, a new phylogenetic analysis (Liu et al. 2011) again supports the former hypothesis that Tardigrada, classical lobopodians and Onychophora form a monophylum that was called Pararthropoda (Cuénot 1926 fide Vandel 1949, but is here thought to also include the pentastomids), Lobopoda (sensu Waggoner 1996) or Tardipolypoda (Chen \& Zhou 1997). Although the most recent phylogenetic analysis of the lobopodians is based on a great number of species and characters, cladistic analyses of this group may be contradictory since character choices in the fossil remains are limited and subjective selection of the importance of characters may influence the results considerably. In any case, the higher systematics, including the families erected by Hou \& Bergström (1995), cannot be retained in the currently applied manner; however, this revisionary work is beyond the scope of the present study.

Provisionally, we apply here the term Lobopodia (sensu Hou \& Bergström, 1995) to the clade including the classical lobopodians and Onychophora. It is worth noting that Snodgrass (1938) did not erect Lobopodia as a taxonomic rank and only used the term "lobopod" as a descriptive term for a specific type of limb.

Lobopodia sensu Hou \& Bergström, 1995

\section{Genus Hallucigenia Conway Morris, 1977}

Type species. - Hallucigenia sparsa (Walcott, 1911).

Remarks. - Two species have been described prior to the herein reported new species from the Guanshan fossil $L a$ gerstätte: the Middle Cambrian H. sparsa and the Lower
Cambrian $H$. fortis. Since the first description of the genus by Conway Morris (1977), the dorso-ventral and antero-posterior orientation of the reconstructed animal has changed. It is remarkable that $H$. sparsa is currently reconstructed with a long slender head, whereas $H$. fortis displays an expanded and rounded head in all cases. Continued preparation of the holotype of $H$. sparsa shows a similar rounded structure as in $H$. fortis at the part now considered to represent the tail, leading Conway Morris (1998) to doubt the generally accepted antero-posterior orientation (Ramsköld \& Chen 1998). New data for reconstructing the animal can be expected from the discovery of new specimens of $H$. sparsa and from a thorough revision of material. Our report of new material of Hallucigenia sparsa from a new region and stratigraphic horizon thus nourishes hopes of the discovery of better preserved material for a detailed restudy of this species.

\section{Hallucigenia sparsa (Walcott, 1911)}

Figures 3, 6K, L

Material. - One sample from the lower Wulongqing Fm., Guangwei town of Kunming district, Yunnan Province, P.R. China showing probably five to six partially decayed and disarticulated individuals on one slab (Figs 3, 6K).

Description. - The partly decayed individuals indicate the preferential preservation of slightly sclerotized sclerites, which always occur in pairs and are often attached to thin remains of a trunk. The remains of trunks are mostly recurved ventrally and are mostly devoid of limbs and remains of heads or tails. One individual preserved weak remains of a leg with more strongly sclerotized curved claws (Figs 3, 6L). Two individuals preserve gut traces (Figs 3, 6L). Sclerites are very slender and partially with longitudinal striation as typically seen in material of $H$. sparsa from the Burgess Shale (Conway Morris 1977, Ramsköld 1992). The type of preservation is similar to that of most specimens from the Burgess Shale, where seven pairs of sclerites are attached to partially decayed trunks without signs of limbs (Conway Morris 1977, pl. 75). The two partially articulated individuals measure between 10 and $12 \mathrm{~mm}$ in total length, and remains of only six pairs of sclerites are preserved. The length of sclerites lies between 2.6 and $4.2 \mathrm{~mm}$, whereas the maximum width ranges from about 170 to $370 \mu \mathrm{m}$. The length/width ratio of sclerites is between 10-18, but mostly 12-14, which exactly matches the length/width ratio of articulated specimens of $H$. sparsa from the Burgess Shale with 12-18. The sizes of total body length, sclerite length and width are also comparable with the smaller individuals from the Burgess Shale (e.g. spines of 2.7-3.2 mm length at a total body length of about $12 \mathrm{~mm}$ ), although larger individuals with up to about 


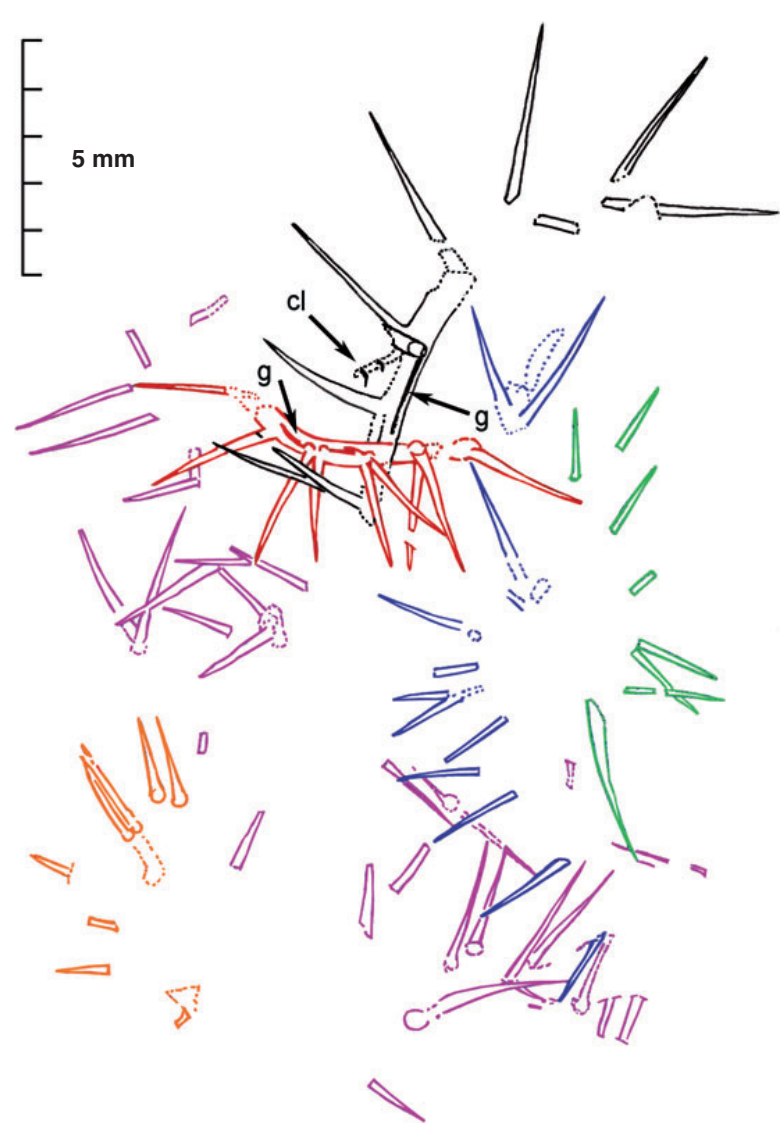

Figure 3. Camera lucida drawing of Hallucigenia sparsa from the lower Wulongqing Fm., Guangwei, Kunming; different colours indicate probably different individuals; pinkish colour refers to disarticulated sclerites probably belonging to one or more individuals; arrows point towards remains of guts (g) and claws (cl); specimen No. GKG 224 (see Fig. 6K).

$2.2 \mathrm{~cm}$ body length and spines of 7.7 to $9.3 \mathrm{~mm}$ length are also known here.

\section{Hallucigenia hongmeia sp. nov.}

Figures 4, 5, 6A-J, M, 7, 11

Holotype. - No. GKG 223 (Figs 5, 6A, B, D, E) from lower Wulongqing Fm., Guangwei town of Kunming district, Yunnan Province, P.R. China; Repository at Yunnan Geological Survey, Kunming.

Etymology. - Named after Li Hongmei, who discovered the first specimen of Hallucigenia in Guangwei and donated the specimen to our research.

Diagnosis. - A slender lobopodian with an annulated trunk with seven pairs of sclerites, eight pairs of legs, and a short tail. The sclerites are slightly sclerotized and show an antero-posterior differentiation with small, cone-shaped

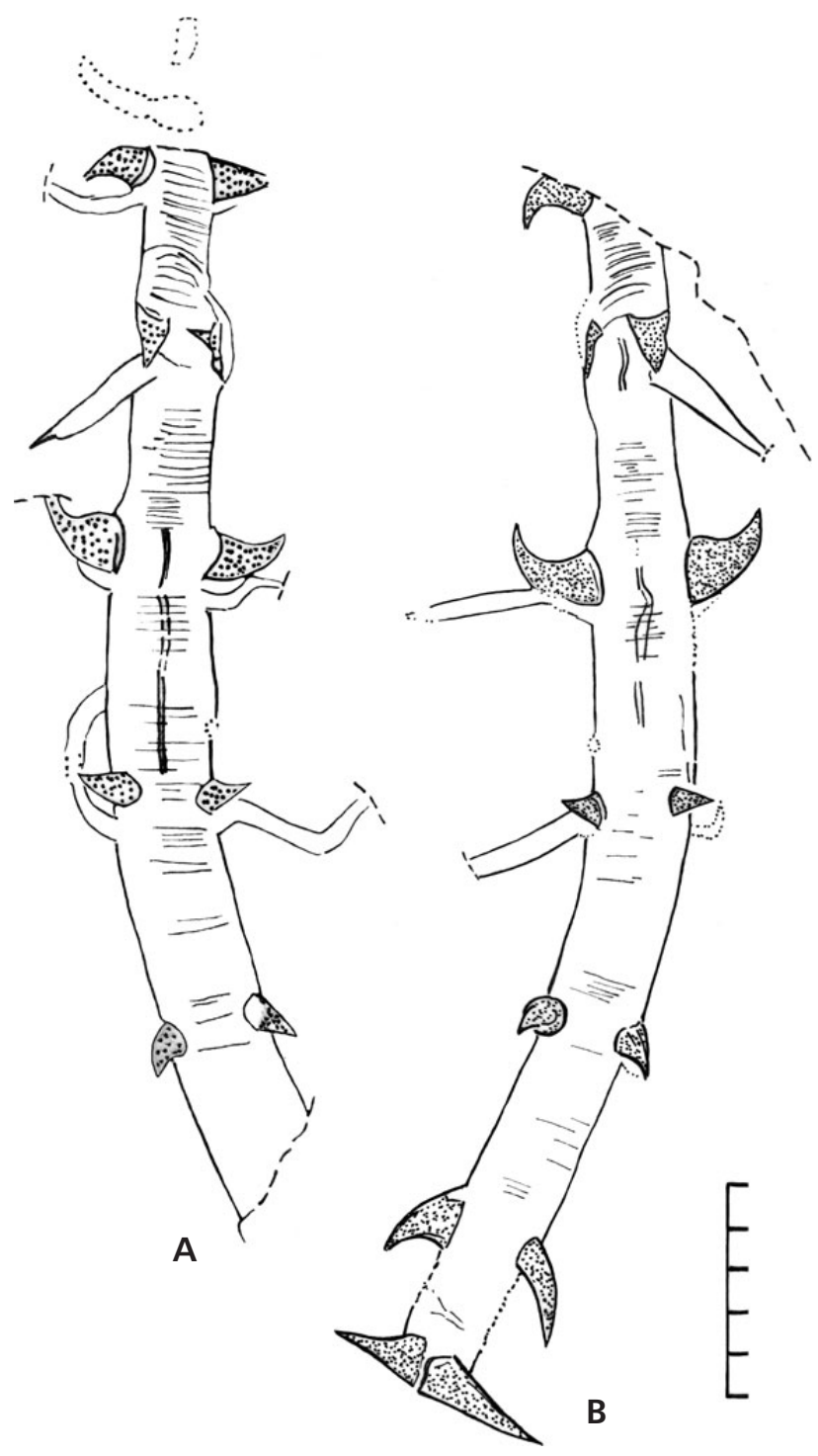

Figure 4. Camera lucida drawing of Hallucigenia hongmeia sp. nov. from the lower Wulongqing Fm., Guangwei, Kunming. • A - specimen No. GKG 225 (see Fig. 6F). • B - specimen No. GKG 225a (see Fig. 6C); scale in millimetres.

sclerites in the middle part and the largest spinose sclerites at the posterior end. Claws of legs are long, curved, and also sclerotized.

Description. - All preserved specimens are incomplete with the head region and the anteriormost appendages in front of plate pair 1 missing. Reconstruction of anterior-posterior orientation is also possible based on the sclerite morphology, since small, cone-shaped sclerites are always observed on segments 4 and 5, whereas the largest spine-shaped sclerites (plate pair 7) occur at the posterior end. The size difference between plates $4 / 5$ and plate 7 is between 180 to $210 \%$ of the size of the smallest sclerite (P 4/5). The variation in the width of sclerites of the same 


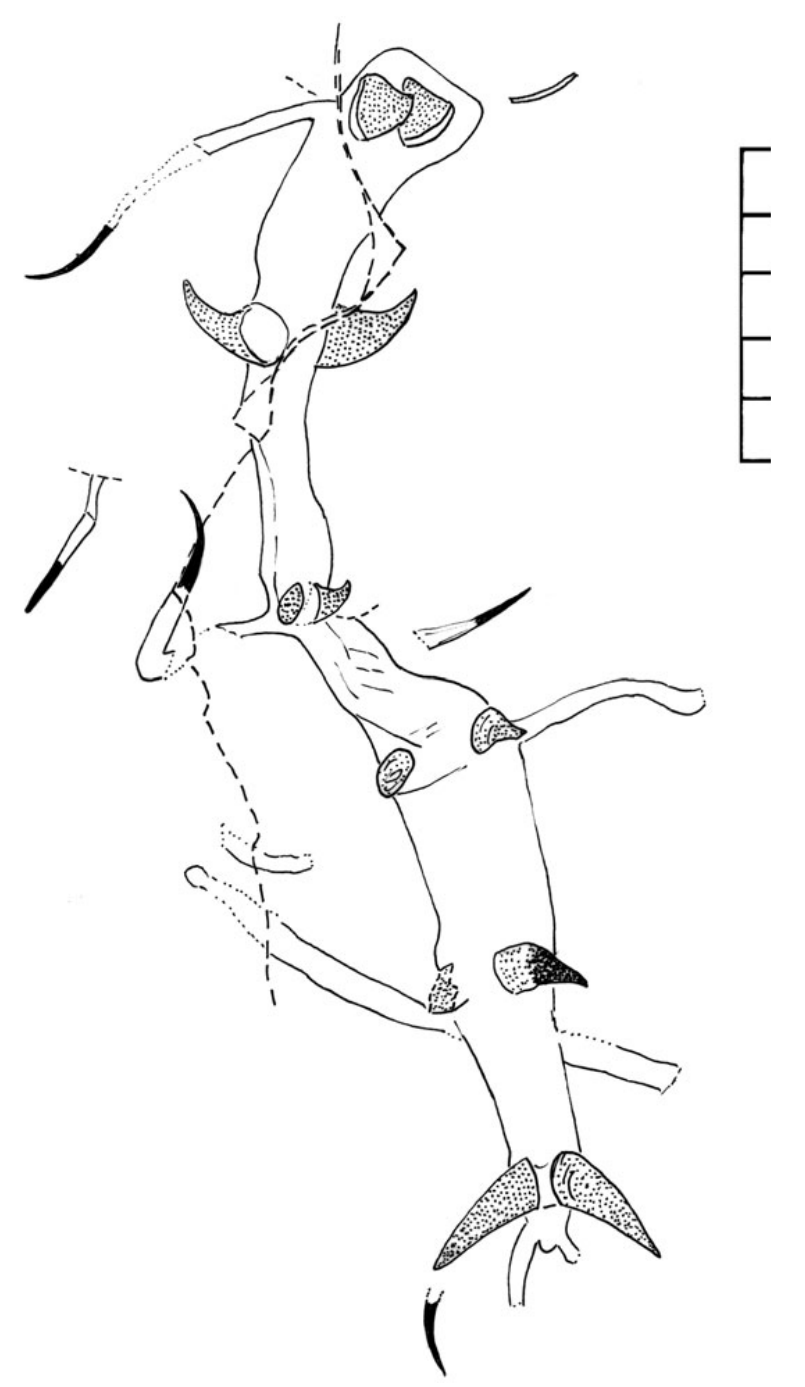

Figure 5. Camera lucida drawing of the holotype of Hallucigenia hongmeia sp. nov. from the lower Wulongqing Fm., Guangwei, Kunming; specimen No. GKG 223 (see Fig. 6A); scale in millimetre. individuals is considerably smaller $(29-106 \%$, mean $=57 \%)$, although here taphonomic differences (e.g. due to variable compaction in the clastic sediments) may have an important impact on measurements. The length of the sclerites lies between $0.48 \mathrm{~mm}$ and $5.1 \mathrm{~mm}$, while their maximum width ranges from about 340 to $1400 \mu \mathrm{m}$ (mean width $=$ $810 \mu \mathrm{m})$. The length/width ratios $(\mathrm{L} / \mathrm{W})$ of plates are specific for the various plate positions in H. hongmeia sp. nov. and also discriminate this species from the other known species of Hallucigenia (see Table 1).

Absolute sclerite size depends on the total body size, which also applies to the other species of Hallucigenia. The sclerites of $H$. hongmeia sp. nov. show a change in direction of inclination in that four anterior sclerites are curved forward and three posterior sclerites are curved backwards. In one specimen (Fig. 6F), the anteriormost sclerite shows a backward inclination, deviating from the general pattern. The sclerites of segment two are often compressed in a dorso-ventral way. The sclerites show a net-like fine structure with openings of about $25 \mu \mathrm{m}$ diameter (Fig. 7B, C, H-K), while the sclerite base has a smooth flange (Figs 6M, 7E-G, I). The large curved claws of the legs are longer than those of most sclerites (Figs 5, 6A, B, D, E), but are so far only well seen in the holotype specimen. Claw length ranges from 1.1 to $1.6 \mathrm{~mm}$.

The trunk width is between 1.1 and $2.1 \mathrm{~mm}$ with about 10-14 annulations per millimetre (Fig. 6M). Thus the annulation appears slightly denser than in $H$. fortis (8-9 per mm, see Ramsköld \& Chen 1998), but this is most likely also influenced by preservational circumstances (e.g. various states of decay or shrinkage, different speed of deposition and embedding, various compaction rates due to minor differences in the composition of embedding mud). The posterior extension of the trunk behind the leg pair 8 is short and rounded (Fig. 6B). One specimen (Figs 4, 6C, F, J)

Table 1. Length to width (L/W) ratios of plates in known species of Hallucigenia.

\begin{tabular}{llccc}
\hline Species & Size range of individuals & L/W plates 1-3,6 & L/W plates 4, 5 & L/W plate 7 \\
\hline H. hongmeia sp. nov. & $\begin{array}{l}21-30 \mathrm{~mm}(7.2-26.4 \mathrm{~mm} ; \\
\text { grouped sclerite clusters) }\end{array}$ & $1.7-2.2$ & $0.8-1.5$ & $2.7-3.5$ (-4.2 disarticulated sclerites, Fig. 7E, F) \\
H. fortis (Chengjiang) & $13-24 \mathrm{~mm}$ & $\begin{array}{l}3.7-5.6 \text { (mean 4.5; no variation between plate position) } \\
\text { H. sparsa (Burgess Shale) }\end{array}$ & $12-22 \mathrm{~mm}$ & 12-18 (no variation between plate position) \\
\hline
\end{tabular}

Figure 6. Hallucigenia hongmeia sp. nov. (A-J, M) and Hallucigenia sparsa (K, L) from the lower Wulongqing Fm., Guangwei, Kunming. - A - holotype No. GKG 223, incomplete individual with anterior part missing. $\bullet$ B - close up of A, illustrating posterior part of animal with plate pairs 6 and 7 and visible legs 6 and 8 and a curved claw of leg 7. $\bullet$ - specimen No. GKG 225, dorsal view of body with plate pairs 1-7, anterior and posterior part incomplete. $\bullet \mathrm{D}$ - close up of A showing left leg3 with long curved claw, and claw of leg2. $\bullet$ E - close up of A showing left leg1 with claw. $\bullet \mathrm{F}$ - counterpart specimen No. GKG 225 a, only body from plate pair 1 to 5 preserved. $\bullet \mathrm{G}$ - partially articulated row of 6 plate pairs without preserved soft-tissues, No. GKG 222. $\bullet \mathrm{H}$ - partially articulated row of 7 plate pairs without preserved soft-tissues, No. GKG 221. $\bullet$ I - partially articulated row of 7 plate pairs without preserved soft-tissues, No. GKG 220. $\bullet$ J close up of F showing plate pair 3 and traces of gut. $\bullet \mathrm{K}-$ overview of specimen No. GKG 223,5 to 6 more or less decayed individuals with two of them partially articulated. $\bullet$ - detail of $\mathrm{K}$, part of the two partially articulated individuals with traces of gut. - M - close up of F, illustrating the annulated trunk; arrows point towards remains of guts (g) and claws (cl); scale equals one millimetre. 
Michael Steiner et al. • Cambrian Hallucigenia and the structure of sclerites in lobopodians
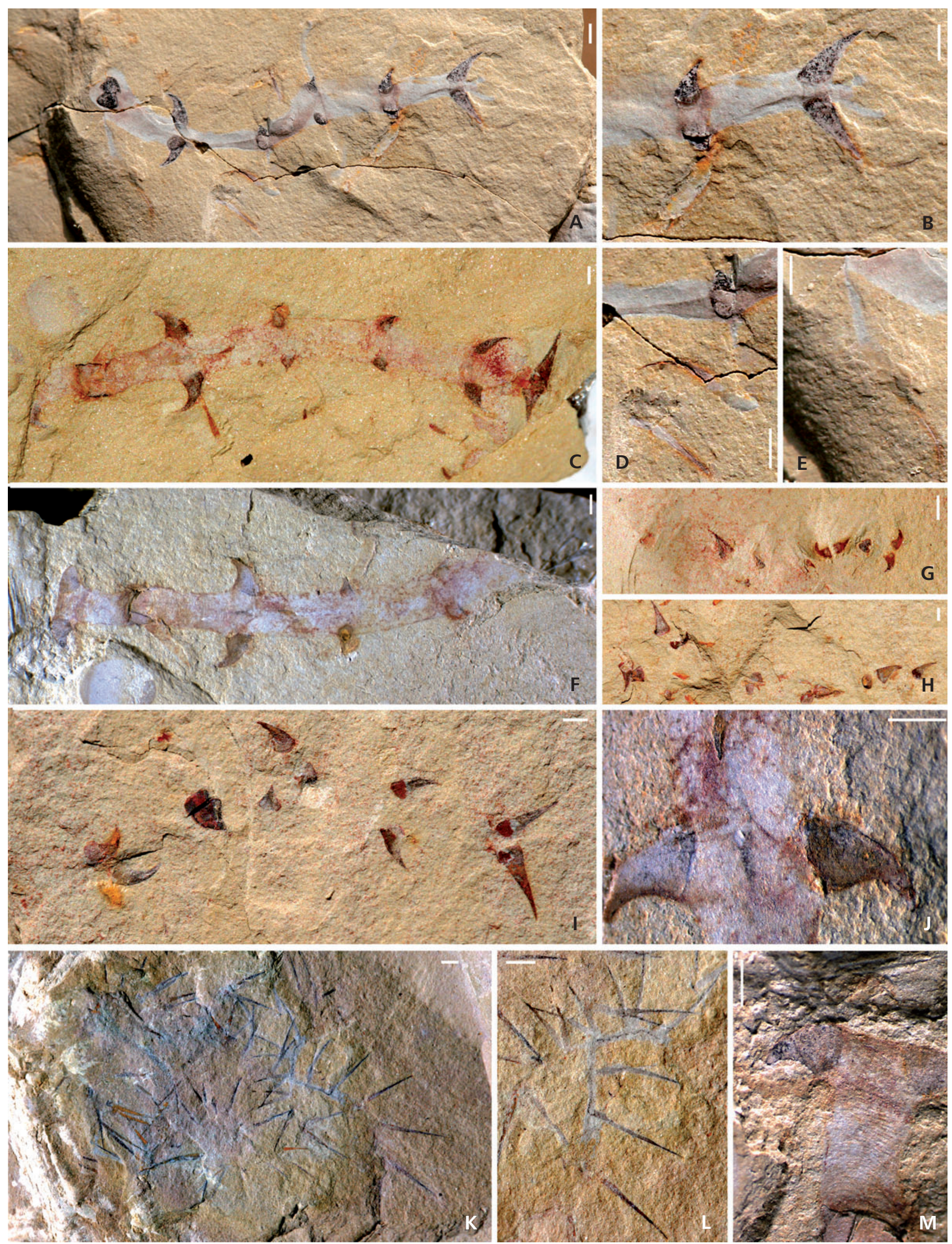
indicates gut traces, which show no clay infilling. It is remarkable that two soft-tissued individuals are sharply truncated in front of plate pair one (Figs 4, 6F) and plate pair two, respectively (Figs 5, 6A) with all unprotected head regions missing.

Material. - Three partially preserved individuals with preserved soft tissue on two slabs (GKG 223, GKG 225). Three specimens of partially articulated rows of sclerites (six to seven pairs of sclerites), without remains of delicate tissues, however. More than 10 samples of disarticulated sclerites and single pairs of sclerites.

\section{The structure and preservation of sclerites}

A number of lobopodian species (Microdictyon, Cardiodictyon, Hallucigenia, Onychodictyon, Luolishania, Miraluolishania, "Collins monster") that are closely allied with the onychophorans have sclerotized sclerites that are symmetrically arranged along the trunk, mostly in pairs dorsally positioned to the walking limbs. The newly described lobopodian-like Diania cactiformis shows numerous sclerites; however, in contrast to the typical Onychophora-allied lobopodians they cover most of the limbs and trunk and are most prominent at the legs. Sclerotization and formation of sclerites is usually not seen in the limbs of lobopodians, except for the terminal claws, which appear to have formed distinct and hardened structures, such as those well illustrated in Onychodictyon (Fig. 8C, G-J; Ramsköld 1992) or in Hallucigenia hongmeia sp. nov. (Fig. 6A, B, D, E).

Despite some influence of weathering, the new material of Hallucigenia from the Wulongqing Fm. is in an excellent state of preservation, which is indicated by the presence of organic carbon in the compressed fossil and fine structures within sclerites (Fig. 7A, C, G-J). Elemental mapping of an individual of the soft-tissued $H$. hongmeia sp. nov. and of its sclerites revealed that the fossil is preserved by residual carbon with strongest concentrations within the gut and the sclerites (Fig. 7A-D). As is typical for the soft-tissue preservation in the Chengjiang-type fossil Lagerstätten of Yunnan, where the slightly weathered individuals are also replicated by iron oxy-hydroxides, this pattern can also been seen in the Guanshan fossil Lagerstätte (Fig. 7D). However, here the strongest iron mineral replication is mostly along cavities or folds and not regularly on the organic tissue. Dispersed sclerites may show a precipitation of cubic Fe-minerals in the inner cavities-possibly originally pyrite (Fig. 7G, K). The irregular distribution and concentration along folds, cracks and margins hints at a secondary process that triggered the secondary Fe-mineral precipitation that was not crucial to the preservation of labile tissues.

The detailed study of the fine structure of articulated and disarticulated sclerites of $H$. hongmeia sp. nov. indicates a net-like pattern within the organic, originally sclerotized matter, with circular openings of about $25 \mu \mathrm{m}$ diameter (Fig. 7A-C, H-J). Fe-minerals, most probably Fe-oxy-hydroxides, are also regularly distributed on the organic matrices of sclerites. In contrast to the cubic cavity infills of sclerites, these Fe-minerals associated with the net-like sclerite matter form fibrous rings around the openings (Fig. 7J middle and right). The carbon distribution also shows the existence of some organic clots within holes of net-like sclerites. These could possibly be interpreted as remains of less sclerotized papillae, which have been documented in the Furongian lobopodian Ostenotubulus evamuuellerae and also lie in the same size range in modern onychophorans (Maas et al. 2007).

The remains of Hallucigenia sparsa from the Wulongqing Fm. are not well preserved enough to reveal the fine structure of sclerites; however, as in the typical material from the Burgess Shale, a longitudinal striation has been partially preserved in some trunk sclerites. This sparse longitudinal striation may be derived from collapse structures of internal cavities of the very slender sclerites.

A similar structure of sclerites as seen in H. hongmeia sp. nov. was recognized in Onychodictyon ferox from the slightly older Yuanshan Formation. Mappings of residual carbon of sclerites and secondary electron images also revealed a net-like pattern with circular openings of about 20-30 $\mu \mathrm{m}$ in diameter (Fig. 8D, F, O). Light-microscopic and BSE images of sclerites show darker structures of 20 to $40 \mu \mathrm{m}$ diameter (Fig. 8E, M, N, P), which resemble the organic carbon clots in the holes of net-like sclerites of Hallucigenia, surrounded by a regularly arranged net with five to six nodes surrounding each opening. Elemental

Figure 7. Hallucigenia hongmeia sp. nov. • A-C- Back Scatter Electron (BSE) image of specimen GKG 225a (see Fig. 6F); B - enlarged right trunk sclerite 2 with net-like structure; C - enlarged left trunk sclerite 2 with net-like structure. $\bullet$ D - elemental map of carbon (C K alpha-left), iron (Fe K alpha-mid), and light microscopic image of same mapped region of left trunk sclerite 3 shown in A. $\bullet$ E - disarticulated sclerite with smooth flange and undulating margin at the base, specimen Shit Low $111 . \bullet \mathrm{F}-$ pair of disarticulated sclerites with smooth flange, specimen Shit Low 113 . $\bullet \mathrm{G}-$ disarticulated sclerite with smooth flange, frames show mapped area shown in H-K, specimen Shit Low 105. • H, J - elemental maps of carbon (C K alpha-left) indicating a net-like organic structure of sclerite, elemental map of iron (Fe K alpha-mid), and BSE image of same area shown in G. $\bullet$ I- elemental map of carbon (C K alpha) of area shown in G. $• \mathrm{~K}$ - BSE image of Fe oxy-hydroxide pseudomorphic crystallites filling the internal cavity of sclerite illustrated in G; specimens with prefix Shit housed at FU Berlin; scale equals one millimetre. 


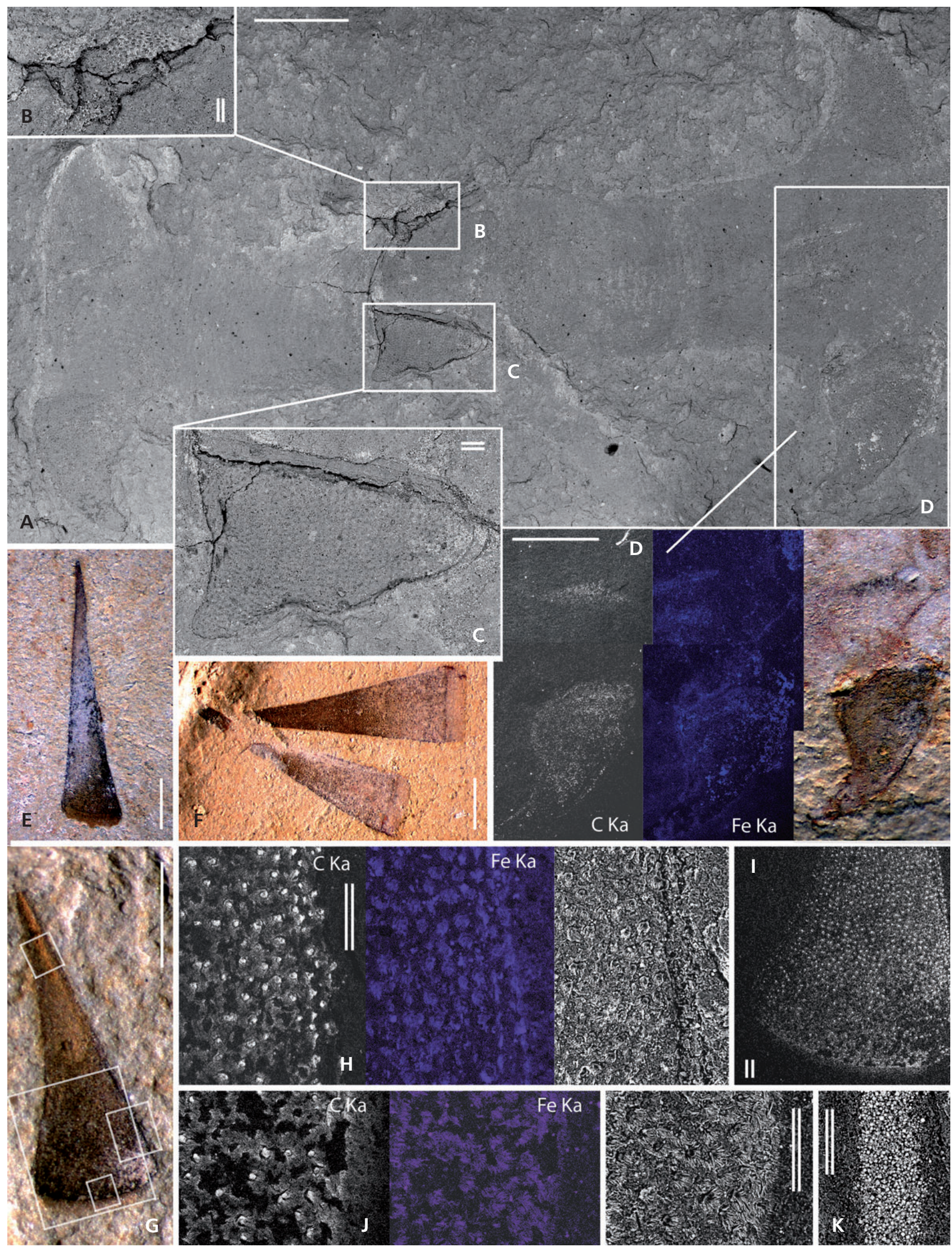


mapping also indicate that Fe-minerals do not replicate the net-like structure and are only enriched at few sclerite margins or folds (Fig. 8D, O). Phosphorus or other elements except carbon and iron are not enriched in either Hallucigenia or Onychodictyon sclerites studied herein. However, the structure, pore sizes, and overall dimensions in sclerites from articulated individuals of Onychodictyon ferox are identical with those of disarticulated phosphatic sclerites described as Onychomicrodictyon spiniferum from the Toyonian of Siberia (Demidenko 2006) and an undetermined sclerite thought to combine features of Microdictyon and Hallucigenia from Greenland (Bengtson 1991). The difference between the chemical composition in lobopodian sclerites from the shale-hosted Burgess Shale-type fossil Lagerstätten and the mostly carbonatehosted, so-called small shelly fossils is most likely due to different taphonomic pathways. Thus, Onychomicrodictyon spiniferum most probably represents a junior synonym of Onychodictyon ferox.

A similar difference exists in the preservation of netlike sclerites of the small shelly material and articulated specimens of Microdictyon from Burgess Shale-type fossil Lagerstätten such as Chengjiang or Kaili. Dispersed sclerites of Microdictyon and the related genus Quadratapora are always preserved as phosphatic net-like three-dimensional structures, whereas those in articulated individuals of Microdictyon from the Chengjiang fossil Lagerstätte never showed any phosphatic remains. This disparity in the mode of preservation might be interpreted in different ways: either all analysed articulated specimens are so strongly weathered that all phosphate was dissolved or the disarticulated sclerites of the small shelly assemblages were secondarily phosphatized. Most researchers support a primary phosphatic nature of sclerites of Microdictyon and Quadratapora, due to the wide distribution in a similar preservation (Bengtson et al. 1986, Bengtson 2004). However, this common view has been challenged by new interpretations - mostly based on crumpling and moulting structures (Fig. 9D) - that the sclerites might have been entirely or partially organic in preservation (Chen et al. 1995, Steiner 2008). In modern metazoans primary phosphate is rare, and lingulid brachiopods include the best-studied examples for this type of biomineralization. The organic material may form a high percentage of the organo-phosphatic shell in some extant species such as Lingula adamsi, where shells also may show crumpling. In similarity to the phosphatic small shelly fossils extinct lingulid brachiopods only preserve extremely rarely organic remains but often consist of diagenetic phosphate.

Elemental mapping of articulated specimens of Microdictyon from Chengjiang indicate a strong residual organic composition of the net-like structure (Fig. 9E, G), although cavities are sometimes present in the trunk sclerites that also reveal some later dissolution (?of phosphate or Fe-minerals) or strong shrinkage and oxidation of a thick organic skeleton. Secondary Fe enrichments are the only other elemental signatures except for residual carbon that are significantly confined to the skeletal structure (Fig. 9E, G). In some least weathered specimens of partially articulated individuals of Microdictyon, a very thin organic film can be recognized that partially or completely sealed the holes in the net-like sclerites (Fig. 9F). It can be postulated that decay of this outer organic layer may have influenced the preservational potential of the node-like (partially mushroom-like) thickenings that have been considered an important character for the erection of numerous part-based skeletal taxa. The principal structure of the net-like sclerites of Microdictyon and Quadratapora is similar to that of the trunk sclerites of Hallucigenia and Onychodictyon; however, in the former ones we could recognize only a thin organic lamella that covers the holes of sclerites, whereas in the latter genera thicker organic nodes are seen filling the holes.

The sizes of holes in the net-like sclerites of Microdictyon have a wider range (mostly $10-100 \mu \mathrm{m}$, but partially up to $160 \mu \mathrm{m}$ ) than in Hallucigenia or Onychodictyon (mostly 20-40 $\mu \mathrm{m}$ ), while those in Quadratapora are better comparable and range from 10 to $35 \mu \mathrm{m}$.

At this point it is remarkable that paired rows of net-like sclerites, reminiscent of trunk sclerites of Microdictyon/ Quadratapora or Onychodictyon, have also been reported

Figure 8. Onychodictyon ferox from the Yuanshan Fm. of Mafang, Kunming. A - overview on an almost complete individual, head part oriented to the left, with no indication of a head shield, No. YDKS 12. • B - detail of trunk and plate pair 7 shown in A, note darker organic gut with partial 3D clay infill, under ethanol submersion. $\bullet \mathrm{C}-\mathrm{BSE}$ image of leg 6 indicating darker organic matter in the leg and paired terminal claws, detail of A and G. $\bullet$ D - elemental maps of carbon (C K alpha-left) and iron (Fe K alpha-right) of same area shown in B. $\bullet$ E - BSE image of sclerite, same area as shown in mapping of D. - F - SEM image of unsputtered sclerite illustrating the net-like structure, same area as shown in B and E. $\bullet \mathrm{G}-$ detail of legs 6 and 7 shown in A, under ethanol submersion. $\bullet \mathrm{H}$ - detail of lobopod shown in $\mathrm{K}$, under ethanol submersion. $\bullet \mathrm{I}-$ detail of paired, sclerotized claws of lobopod shown in $\mathrm{H}$, under ethanol submersion. $\bullet \mathrm{J}$ - detail of paired terminal claws of lobopod 7 shown in $\mathrm{G}$, under ethanol submersion. $\bullet \mathrm{K}-$ overview of incomplete individual with anterior and posterior parts missing, arrows point toward 3D gut infill of coarse grained particles, low angle light, No. MF 012 (specimen deposited at Northwest University, Xi' an). $\bullet \mathrm{L}$ - same as $\mathrm{K}$, high angle light. $\bullet \mathrm{M}$ - detail of plate pair and part of organic gut shown in $\mathrm{K}$, note darker organic gut with partial 3D clay infill, under ethanol submersion. $\bullet \mathrm{N}$ - detail of net-like structure of plate shown in $\mathrm{M}$, under ethanol submersion. $\bullet \mathrm{O}-$ elemental maps of carbon (C K alpha-left) indicating a net-like organic structure of sclerite, elemental map of iron (Fe K alpha-right) of same area shown in M. $\bullet$ P - BSE image of sclerite, same area as shown in mapping of $\mathrm{O}$; scales equals one millimetre. 


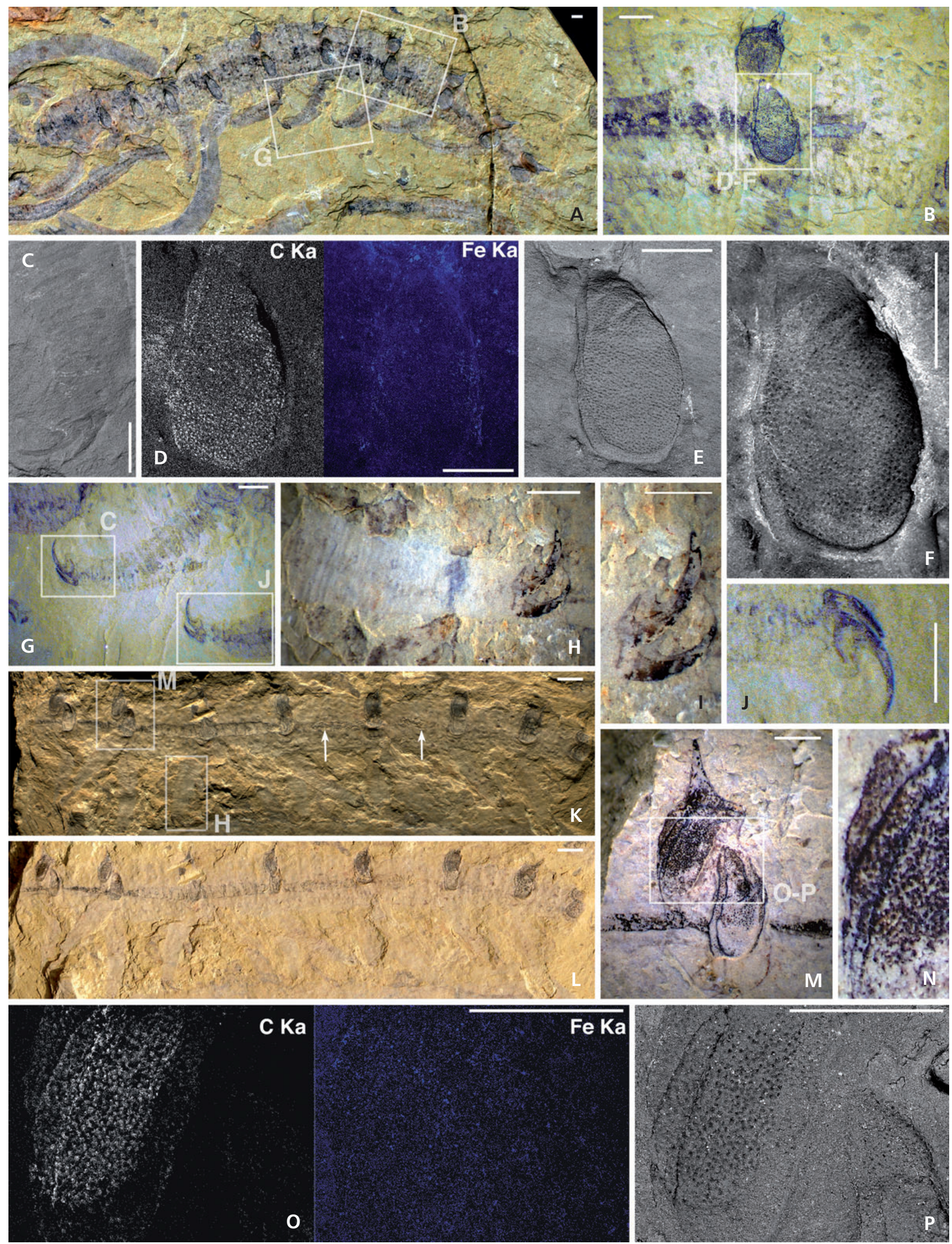


Table 2. Overview on preservational and structural data of net-like plate bearing taxa of lobopodians and extinct cycloneuralians. For references see text.

\begin{tabular}{lll}
\hline Taxon & Preservation of sclerites & Sizes of holes in net-like sclerites \\
\hline Hallucigenia hongmeia sp. nov. & Organic & ca $25 \mu \mathrm{m}$ \\
Microdictyon & Organic / phosphatic & Mostly 10-100 $\mu \mathrm{m}$, up to $160 \mu \mathrm{m}$ \\
Quadratapora & Phosphatic & $10-35 \mu \mathrm{m}$ \\
Onychodictyon & Organic; phosphatic (“Onychomicrodictyon”) & ca $20-40 \mu \mathrm{m}$ \\
Cricocosmia & Organic; Fe-replacement & $10-15 \mu \mathrm{m}$ \\
Tabelliscolex & Uncertain; Fe-replacement? & ca $20-30 \mu \mathrm{m}$ \\
\hline
\end{tabular}

from two species of palaeoscolecidans sensu lato (Fig. 10; Han et al. 2007) from the Chengjiang-type fossil Lagerstätten-Cricocosmia jinningensis and Tabelliscolex hexagonus. Cricocosmia has rather small and flat conical trunk sclerites with a net-like structure (see Han et al. 2007) and a basal smooth flank. The micro-structures of these sclerites are rarely recognized and lie in the lower size range (overall size of sclerite about $350-550 \mu \mathrm{m}$, holes of net-like structure about $10-15 \mu \mathrm{m}$ ) of lobopodian sclerites. Previous elemental analysis of sclerites showed that they mostly consisted of Fe compounds (Han et al. 2007). However, here we can prove that also these sclerites are composed of residual carbon (Fig. 10A-C). Trunk sclerites of Tabelliscolex are larger (about 1-1.6 mm), elongated, and with a net-like structure (see Han et al. 2007) that does not show the nodes seen in Microdictyon plates. The holes of trunk sclerites of Tabelliscolex are comparable in dimension (about 20-30 $\mu \mathrm{m}$ ) with those in net-like sclerites of lobopodians. The reported chemical composition of sclerites of Tabelliscolex as apatitic and pyritic is not conclusive according to the presented elemental maps and area analysis (Han et al. 2007) and tends to support a replication of organic structures by Fe-minerals (most probably Fe-oxy/hydroxides). Remarkable similarities also exist between the trunk sclerites in Tabelliscolex and regions of the cuticle in Houscolex where densely packed larger pores of the size of 8-15 $\mu \mathrm{m}$ penetrate the cuticle (see Zhang \& Pratt 1996) and show a roughly hexagonal net-like pattern. The holes are often sealed by a slightly collapsed membrane that seems to be less resistant than the rest of the cuticle (compare Zhang \& Pratt 1996, fig. 2.10-13). Although these membranes have been termed plates in the original description (Zhang \& Pratt 1996), we think that they are not strongly mineralized or sclerotized structures like those in other palaeoscolecidans. However, in contrast to the net-like sclerites in Tabelliscolex, which are more sharply delimited and also exhibit a marginal flange as in other net-like sclerites of lobopodians, the porous, net-like regions in the cuticle of Houscolex are rather transitional to other cuticle ornamentation, less sharply delimited and apparently more flexible. Thus, these regions in the cuticle fragments of Houscolex appear to be less sclerotized than sclerites of other palaeoscolecidans and lobopodians.

Sclerites of the lobopodians Hallucigenia fortis, Miraluolishania haikouensis, Luolishania longicruris and Cardiodictyon catenulum from the Chengjiang-type Lagerstätten of Yuanshan Formation have also been studied for their detailed structures; however, the material presently at hand was too strongly affected by replacement by secondary Fe-minerals (Fig. 9H-K) to reveal its primary micro-structure.

It is also worth noting that the net-like structures described herein from sclerites of the lobopodian genera Hallucigenia, Onychodictyon and Microdictyon are not seen in the sclerotized claws of the same taxa. This is not surprising; however, it documents that the recorded structure in trunk sclerites of Hallucigenia and Onychodictyon is not a

Figure 9. Microdictyon sinicum from Jiangshan (A-C, E), Maotianshan (D), and from Ercaicun, Haikou, Kunming (F, G); Hallucigenia fortis (H, K) from Jiangshan; Luolishania longicruris (I, J) from Mafang, Kunming; all from Yuanshan Fm. • A - overview of two almost complete individuals, head parts oriented to the left, No. YDKS 18. $\bullet$ B - detail of trunk and plate pairs 8 and 9 shown in A. $\bullet$ C - BSE image of plate pair 8 shown in B. - D - incomplete individual, arrow points toward a duplication of sclerite, probably due to moulting, No. P5250012. $\bullet$ E - elemental maps of carbon (C K alpha-left), carbon enrichment replicates the net-like structure of sclerite, elemental map of iron (Fe K alpha-mid-left), elemental map of $\mathrm{Ca}$ (Ca K alpha-mid-right), and elemental map of $\mathrm{P}$ (P K alpha-right), the latter two revealing no remnants of calcium phosphate, all of same area shown in B and C. $\bullet \mathrm{F}$ - plate pair of an incomplete individual, arrow points toward an organic layer partially or fully covering the holes of sclerites, No. Hz-f-4273. • G - elemental maps of carbon (C K alpha-left) and iron (Fe K alpha-right) of same sclerites shown in F. • H - overview of incomplete individual with 7 pairs of sclerites and bulbous head (pointing toward right), No. JS 0005A (specimen deposited at Northwest University, Xi'an). - I- overview of an incomplete individual with 10 paired sclerites and a central node preserved, arrow points toward sclerite shown in J, No. YDKS 15 . - J - BSE image of sclerite completely replaced and covered with micro-crystallites of iron minerals. $\bullet \mathrm{K}$ - elemental maps of carbon (C K alpha-left) and iron (Fe K alpha-right) of same sclerite 7 shown in $\mathrm{H}$, only tip of sclerite retains carbon signal, otherwise replaced by iron phases; single lined scale equals one millimetre, double lined scale equals $100 \mu \mathrm{m}$. 
Michael Steiner et al. - Cambrian Hallucigenia and the structure of sclerites in lobopodians

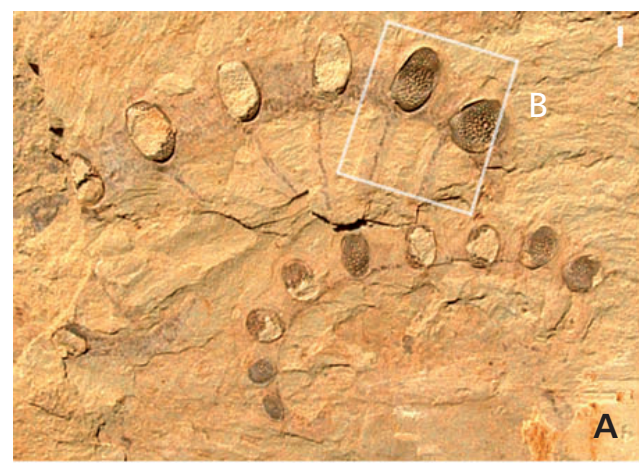

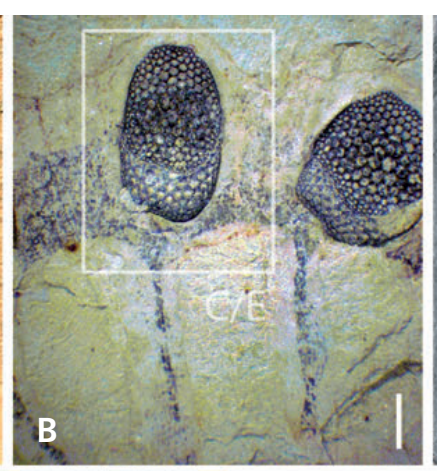

Ca Ka

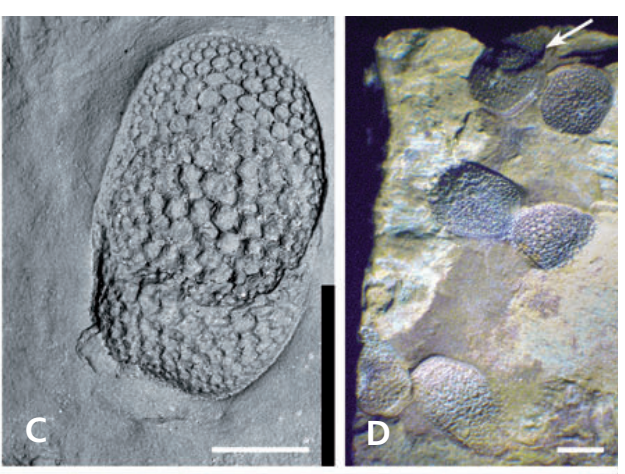

P Ka
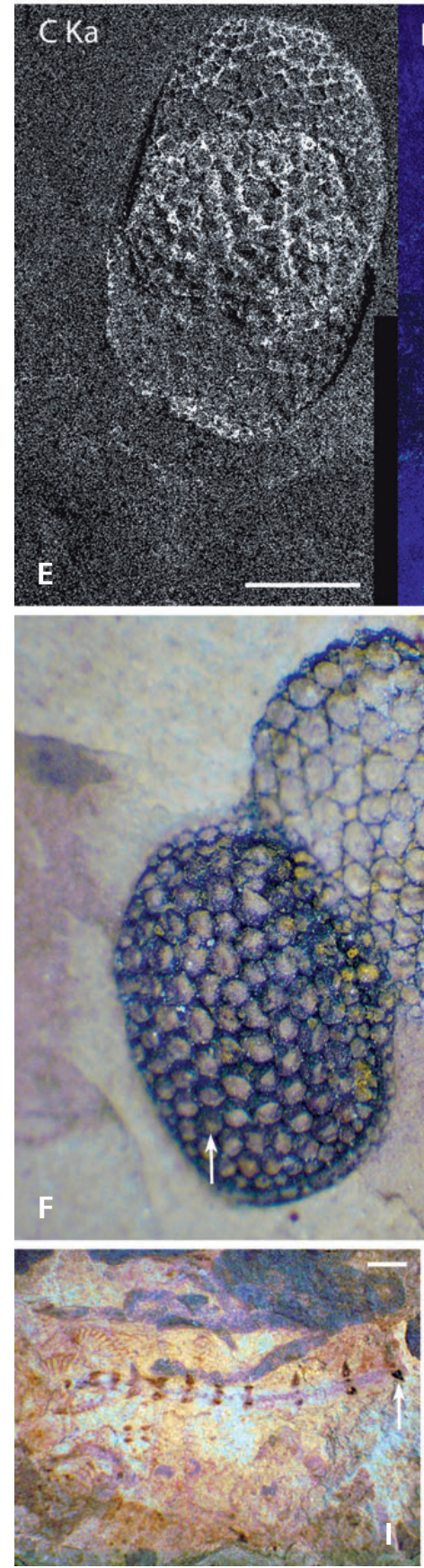

Fe Ka
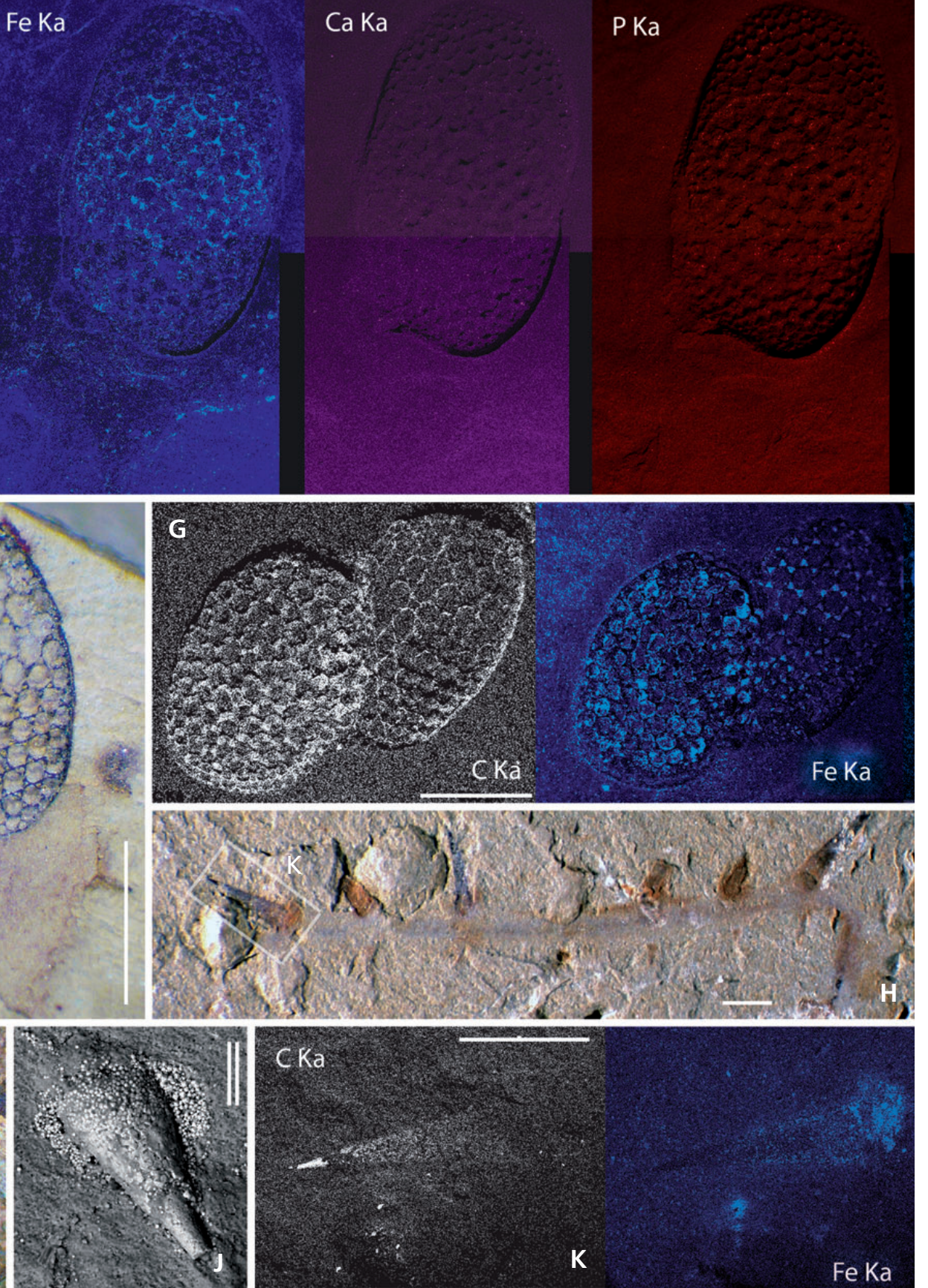

Fe Ka 

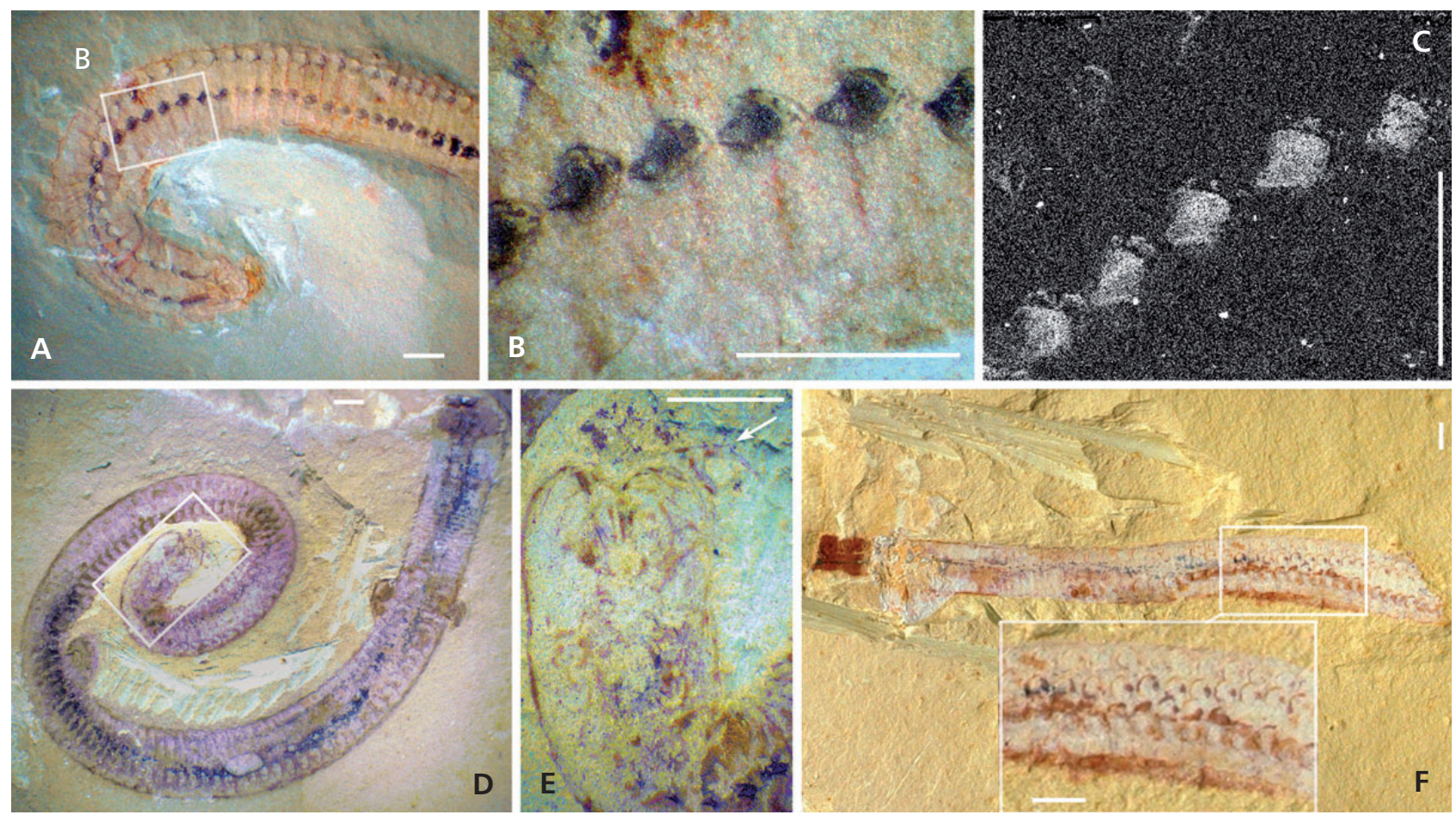

Figure 10. Cricocosmia jinningensis from the Yuanshan Fm., Yulongsi (A-C) and Mafang (D-F), Kunming. • A - overview of posterior part of individual, note one pair of sclerites per annulation and last pair of sclerites with deviating elongated shape, No. Yul 001 . $\bullet$ B - detail of plates shown in A, in ethanol submersion. - $\mathrm{C}$ - elemental map of carbon (C K alpha-left) of same sclerites shown in B. $\bullet$ D - overview of complete curled individual, No. Maf-b-100a. $\bullet$ E - detail of posterior part with terminal hook of area shown in D, in ethanol submersion. $\bullet \mathrm{F}-$ incomplete individual with preserved proboscis and four rows of sclerites, probably due to moulting, enlargement shows the duplication of sclerites, No. Maf-b-125b; scale equals one millimetre.

preservational artefact. In contrast to the trunk sclerites, the claws of Onychodictyon are formed by a thick and uniform organic cuticle that resembles some protoconodonts in shape. However, this morphological similarity is superficial, and a comparison of lobopodian claws (Hou \& Bergström 1995 ) with the protoconodont Mongolodus does not hold true since clusters of Mongolodus protoconodonts support an interpretation as grasping hooks of arrow worms (Vannier et al. 2007). A morphological similarity also exists between the terminal claws of lobopods and the posterior hooks of Cricocosmia (Fig. 10E) and other Cambrian priapulids that appear slightly sclerotized.

\section{Discussion and conclusions}

Lobopodians have been mostly described from the Cambrian Stage 3 Chengjiang-type fossil Lagerstätten, the traditional Middle Cambrian Burgess Shale, Utah Lagerstätten and the Kaili fossil Lagerstätte. The herein described new material of $H$. hongmeia sp. nov. and Hallucigenia sparsa from the lower Wulongqing Formation adds new insights into lobopodian diversity from the intermediate Cambrian Stage 4. Individuals of H. hongmeia sp. nov. indicate stronger similarities with $H$. fortis, al- though no head parts and anteriormost appendages to date have been observed (Fig. 11). The comparatively simple bauplan of lobopodians and the few discriminative characters that are retained in the soft-tissued Burgess Shale-type fossil Lagerstätten represent a challenge to a rigid phylogenetic analysis of the lobopodians and lobopodian-like organisms. Therefore, detailed data on the microstructure and primary composition of sclerites may contribute to a thorough phylogenetic analysis of lobopodians.

Owing to the similarities of the paired, net-like trunk sclerites in Hallucigenia, Onychodictyon, and Microdictyon, it is proposed that these structures represent homology, which also may be postulated for the other lobopodians more closely allied to the Onychophora, such as Miraluolishania, Luolishania and Cardiodictyon. However, except for the general shape and position of the paired sclerites, no details exist so far on the microstructure of the sclerites of the latter three genera that might further support our assumption. Except for the paired trunk sclerites and sclerotized claws, there exist no further sclerotized plates in lobopodians, although additional head sclerites have been postulated for Cardiodictyon and Hallucigenia by Hou \& Bergström (1995) and for Onychodictyon by Ramsköld \& Chen (1998). 


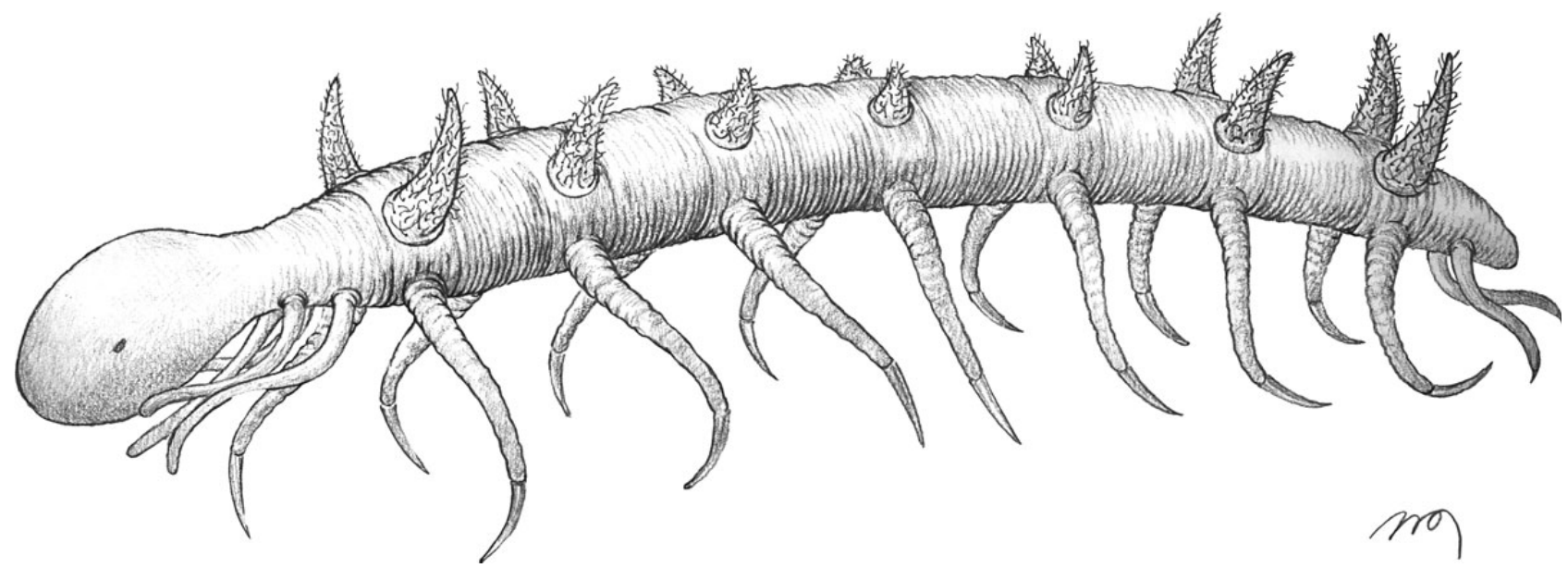

Figure 11. Reconstruction of Hallucigenia hongmeia sp. nov. Note that the head part and anteriormost two appendages in front of plate pair one are entirely hypothetical.

The function of trunk sclerites in lobopodians has been variously discussed and a protective function has been considered most likely (Briggs et al. 1994, Conway Morris 1998). Alternatively it has been suggested that the sclerites framed the body and served to attach muscles (Chen et al. 1989); however, this requires an explanation of the complicated net-like structure, the lack of sclerites at some anterior and posterior segments, and the functionality at very slender and hollow sclerites (like in Hallucigenia sparsa). Although the very large, closely arranged and sharp sclerites of Hallucigenia sparsa may indeed have had a protective function, this scenario would be less likely for the other species of Hallucigenia, especially for $H$. hongmeia sp. nov. with its small, cone-shaped median trunk sclerites. Other lobopodians also do not have larger or densely arranged trunk sclerites that significantly covered the body of lobopodians to provide major protection. For Microdictyon the prominent net-like structure of flat trunk sclerites has given rise to alternative interpretations, such as those of a supportive structure for lateral paired eyes (Dzik 2003). However, true small single eyes have been figured from Miraluolishania, Hallucigenia and Cardiodictyon (Liu et al. 2004, 2008, 2011; for Hallucigenia see Hou et al. 2004, fig. 14.7b, c; Ramsköld \& Chen 1998, fig. 3.3A-C) and a development of serially paired compound eyes above the limbs is functionally unlikely (Zhang \& Aldridge 2007). Our interpretation of net-like trunk sclerites of lobopodians such as Hallucigenia, Onychodictyon and Microdictyon is that they were a supportive structure for secretive or sensory papillae that may have had tactile, chemosensory or secretory functions, which then also might have protected the soft-bodied trunk.

Similar paired net-like sclerites in the palaeoscolecidans sensu lato Tabelliscolex and Cricocosmia are here also seen as homology to the lobopodians and may point to a closer phylogenetic relationship between this specific group of vermiform scalidophorans and the panarthropoda. Tabelliscolex and Cricocosmia are mostly treated as palaeoscolecidans because of their general worm-like body forms with annulations, the presence of an introvert with scalids and one or more terminal hooks (Fig. 10D, E), and the existence of sclerites. However, in contrast to the palaeoscolecidans sensu stricto the sclerites in Cricocosmia and Tabelliscolex are arranged in pairs, indicating a bilateral rather than a radial symmetry (Fig. 10A), are not densely packed in radial patterns, and reveal a characteristic net-like microstructure similar to those in lobopodian trunk sclerites (see Han et al. 2007). Duplication of sclerites, which may be interpreted as moulting structures, have so far only been reported from lobopodians (Fig. 9D; Chen et al. 1995, Zhang \& Aldridge 2007) and Cricocosmia (Fig. 10F). The sclerites of palaeoscolecidans sensu stricto are massive, buttonshaped, but with a lateral flange. Their composition is apatitic, both in articulated and disarticulated specimens. By contrast, the composition of sclerites in Cricocosmia and Tabelliscolex and most lobopodians is interpreted here as primarily organic, although a mixed organo-phosphatic composition with a minor content of phosphorus cannot be completely ruled out. From a theoretic point of view, the stronger primary biomineralization of sclerites by phosphate in frequently moulting lobopodians is also less likely because phosphatization involves high-energy costs, and moulting would regularly cause a loss of these biomineralized structures. Recent phylogenetic analyses of palaeoscolecidans have also considered Tabelliscolex and Cricocosmia as belonging to a sister clade of the palaeoscolecidans sensu stricto (Harvey et al. 2010). If the homology for the sclerites in this clade and those of 
lobopodians can further be supported, the existence of net-like trunk sclerites may be considered as a synapomorphic character for the ecdysozoa. The recent review of anatomy and phylogenetic analysis of the palaeoscolecidans by Harvey et al. (2010) revealed a stem-priapulid or nematomorph position for the palaeoscolecidans that is more remote to the panarthropodans. However, their cladistic analysis did not appear extremely robust and the phylogenetic position of the palaeoscolecidans was strongly influenced by the inclusion of different fossil clades, such as genera of extinct cycloneuralians (e.g. Corynetis, Maotianshania, Ottoia, Tylotites, Cricocosmia, Tabelliscolex). The flexibility of cladistic results may be also due to the fact that the majority of characters for these extinct cycloneuralians, but also the palaeoscolecidans s.s. were stated as unknown or unapplicable (mostly $50-80 \%$ of applied characters). The inclusion of other important taxa to such a cladistic analysis as e.g. Facivermis and the consideration of the herein discussed net-like microstructure of sclerites might in contrast also reveal a so far unrecognized closer relationships between some extinct cycloneuralians and the lobopodians. The enigmatic Facivermis yunnanicus, that had been allied to polychaetes, pentastomids, lophophorates, and lobopodians by various authors, indeed reveals five pairs of appendages similar to those of Miraluolishania (see Liu et al. 2006), but otherwise a smooth to faintly annulated trunk with circles of tiny spines that resembles the trunk of Corynetis brevis. Although we consider Facivermis as closer related to lobopodians and probably adapted to a specialised lifestyle the trunk construction and ornamentation may also hint toward relationships with cycloneuralians.

In contrast to the typical lobopodians, the recently described lobopodian-like Diania cactiformis is densely covered on its limbs and trunk with numerous spinose sclerites that certainly had a mechanical protective function and also enhanced its body rigidity. This massive sclerotization of the outer cuticle also required the development of jointed legs to further promote the flexibility of limbs. This heavier sclerotization is currently only observed in the lobopodian-like Diania and is evidence of a tendency towards partial arthropodization in rather soft-bodied panarthropodans that finally led to the sclerotized exoskeleton of euarthropods. The microstructure of sclerites in Diania differs from the net-like microstructure of trunk sclerites in typical lobopodians.

The smooth, strongly sclerotized and large lobopodian claws point towards an adaption to specific habitats. Especially the larger and slightly curved claws seen in Hallucigenia hongmeia sp. nov. appear less adapted for walking in a muddy substrate than to a climbing mode of life, perhaps on other benthic organisms or larger algae.

\section{Acknowledgements}

This paper is a contribution to the Sino-German collaborative project "The Precambrian-Cambrian biosphere revolution: Insights from Chinese microcontinents" (FOR 736). The work was supported by Deutsche Forschungsgemeinschaft (KE 322/34-1 to M.S. \& H.K.), National Natural Science Foundation of China (Grant No. 40772020 to S.H., grants 40802011, 40830208 to J.L.), Alexander von Humboldt Foundation (J.L.), and the MOST Special Fund from the State Key Laboratory of Continental Dynamics, Northwest University (to J.L.). We are grateful to Bernd Weber (Berlin), Li Guoxiang (Nanjing), Chen Qingtao, and Li Hongmei (Kunming) for help during fieldwork. Chi Mingguang (Berlin) prepared the final version of reconstruction (Figure 11). The helpful reviews by Olaf Elicki and an anonymous reviewer are greatly acknowledged.

\section{References}

Bengtson, S. 1991. Paleontology - Oddballs from the Cambrian Start to Get Even. Nature 351(6323), 184-185.

DOI 10.1038/351184a0

Bengtson, S. 2004. Early skeletal fossils, 67-77. In LipPs, J.H. \& WAGGONER, B.M. (eds) Neoproterozoic-Cambrian biological revolutions. Volume 10. Yale University Reprographics \& Imaging Systems, New Haven, Connecticut.

Bengtson, S., Matthews, S.C. \& Missarzhevsky, V.V. 1986. The Cambrian netlike fossil Microdictyon, 97-115. In HoFFman, A. \& Nitecki, M.H. (eds) Problematic Fossil Taxa. Volume 5. Oxford University Press, New York.

Briggs, D.E.G., ERwin, D.H. \& Collier, F.J. 1994. The fossils of the Burgess Shale. 238 pp. Smithonian Institution Press, Washington \& London.

BuDD, G.E. 1999. The morphology and phylogenetic significance of Kerygmachela kierkegaardi Budd (Buen Formation, Lower Cambrian, N Greenland). Transactions of the Royal Society of Edinburgh, Earth Sciences 89, 249-290. DOI 10.1017/S0263593300002418

Chen, J., Hou, X. \& Lu, H. 1989. Early Cambrian netted scalebearing worm-like sea animal. Acta Palaeontologica Sinica 28(1), 1-16. [in Chinese with English summary]

Chen, J. \& Zhou, G. 1997. Biology of the Chengjiang fauna. Bulletin of National Museum of Natural Science 10, 11-105.

Chen, J., Zhou, G. \& RAmsköLd, L. 1995. The Cambrian Lobopodian Microdictyon sinicum. Bulletin of the National Museum of Natural Science 5, 1-93.

Conway Morris, S. 1977. A new Metazoan from the Cambrian Burgess Shale of British Columbia. Palaeontology 20(3), 623-640.

Conway Morris, S. 1998. The Crucible of Creation. 242 pp. Oxford University Press, Oxford.

CuÉnot, L. 1926. L'entonnoir vibratile de la néphridie des Péripates. Annales de la Société royale zoologique de Belgique 56. 
Demidenko, Y.E. 2006. New Cambrian lobopods and chaetognaths of the Siberian Platform. Paleontological Journal 4O(3), 234-243. DOI 10.1134/S0031030106030026

DzIK, J. 2003. Early Cambrian lobopodian sclerites and associated fossils from Kazakhstan. Palaeontology 46(1), 93-112. DOI 10.1111/1475-4983.00289

DZiK, J. \& Krumbiegel, G. 1989. The oldest "onychophoran" Xenusion: a link connecting phyla? Lethaia 22, 169-181. DOI 10.1111/j.1502-3931.1989.tb01679.x

Gould, S.J. 1989. Wonderful life - The Burgess Shale and the nature of history. 347 pp. W.W. Norton \& Company, New York.

Han, J., Liu, J., Zhang, Z., Zhang, X. \& Shu, D. 2007. Trunk ornament on the palaeoscolecid worms Cricocosmia and Tabelliscolex from the Early Cambrian Chengjiang deposits of China. Acta Palaeontologica Polonica 52(2), 423-431.

Harvey, T.H.P., Dong, X. \& Donoghue, P.C.J. 2010. Are palaeoscolecids ancestral ecdysozoans? Evolution \& Development 12(2), 177-200. DOI 10.1111/j.1525-142X.2010.00403.x

Hou, X.G., Aldridge, R.J., Bergström, J., Siveter, David J., Siveter, Derek J. \& Feng, X.H. 2004. The Cambrian fossils of Chengjiang, China: The flowering of early animal life. 248 pp. Blackwell Publishing, Malden \& Oxford. DOI 10.1002/9780470999950

Hou, X. \& Bergström, J. 1995. Cambrian lobopodians-ancestors of extant onychophorans. Zoological Journal of the Linnean Society 114, 3-19.

DOI 10.1111/j.1096-3642.1995.tb00110.x

Hu, S., Zhu, M., Steiner, M., Luo, H., Zhao, F. \& Liu, Q. 2010. Biodiversity and taphonomy of the Early Cambrian Guanshan biota, eastern Yunnan. Science China, Earth Sciences 53(12), 1765-1773. DOI 10.1007/s11430-010-4086-9

Li, G., Steiner, M., Zhu, X.J., Yang, A., Wang, H. \& Erdtmann, B.-D. 2007. Early Cambrian metazoan fossil record of South China: Generic diversity and radiation patterns. Palaeogeography, Palaeoclimatology, Palaeoecology 254(1-2), 229-249. DOI 10.1016/j.palaeo.2007.03.017

Liu, J., Han, J., Simonetta, A.M., Hu, S., Zhang, Z., Yao, Y. \& SHU, D. 2006. New observations of the lobopod-like worm Facivermis from the Early Cambrian Chengjiang Lagerstätte. Chinese Science Bulletin 51(3), 358-363. DOI 10.1007/s11434-006-0358-3

Liu, J., Ou, Q., Han, J., Zhang, Z.F., He, T.J., YaO, X.Y., Fu, D.J. \& SHu, D. 2012. New occurrence of the Cambrian (Stage 4, Series 2) Guanshan Biota in Huize, Yunnan, South China. Bulletin of Geosciences 87(1), 125-132.

DOI 10.3140/bull.geosci.1229

Liu, J., Shu, D., Han, J. \& Zhang, Z. 2004. A rare lobopod with well-preserved eyes from Chengjiang Lagerstätte and its implications for origin of arthropods. Chinese Science Bulletin 49(10), 1063-1071. DOI 10.1007/BF03184038

Liu, J., Shu, D., Han, J. \& Zhang, Z. 2008. Comparative study of Cambrian lobopods Miraluolishania and Luolishania. Chinese Science Bulletin 53(1), 87-93. DOI 10.1007/s11434-007-0428-1

LiU, J., Shu, D., Han, J., Zhang, Z. \& Zhang, X. 2007. Morpho- anatomy of the lobopod Magadictyon cf. haikouensis from the Early Cambrian Chengjiang Lagerstätte, South China. Acta Zoologica (Stockholm) 88(4), 279-288.

DOI 10.1111/j.1463-6395.2007.00281.x

Liu, J., Steiner, M., Dunlop, J.A., Keupp, H., Shu, D., Ou, Q., Han, J., Zhang, Z. \& Zhang, X. 2011. An armoured Cambrian lobopodian from China with arthropod-like appendages. Nature 470(7335), 526-530.

DOI 10.1038/nature09704

Luo, H.L., Hu, S.X., Chen, L.Z., Zhang, S.S. \& TAO, Y.H. 1999. Early Cambrian Chengjiang fauna from Kunming region, China. 129 pp. Yunnan Science and Technology Press, Kunming, China.

Luo, H., Li, Y., Hu, S., Fu, X., Hou, S., Liu, X., Chen, L., Li, F., PANG, J. \& Liu, Q. 2008. Early Cambrian Malong and Guanshan Fauna from Eastern Yunnan, China. 134 pp. Yunnan Science and Technology Press, Kunming.

Maas, A., Mayer, G., Kristensen, R.M. \& Waloszek, D. 2007. A Cambrian micro-lobopodian and the evolution of arthropod locomotion and reproduction. Chinese Science Bulletin 52(24), 3385-3392. DOI 10.1007/s11434-007-0515-3

Ou, Q., Liu, J., Shu, D., Han, J., Zhang, Z., Wan, X. \& Lei, Q. 2011. A rare onychophoran-like lobopodian from the Lower Cambrian Chengjiang Lagerstätte, Southwestern China, and its phylogenetic implications. Journal of Paleontology 85(3), 587-594. DOI 10.1666/09-147R2.1

PomPeCKJ, J.F. 1927. Ein Zeugnis uralten Lebens. Paläontologische Zeitschrift 9(1-3), 287-313.

RAMSKÖLD, L. 1992. The second leg row of Hallucigenia discovered. Lethaia 25, 221-224.

DOI 10.1111/j.1502-3931.1992.tb01389.x

RAMSKÖLD, L. \& CHEN, J. 1998. Cambrian lobopodians: Morphology and phylogeny, 107-150. In Edgecombe, G.D. (ed.) Arthropod fossils and phylogeny. Columbia University Press, New York.

SCUDDER, S.H. 1890. New Carboniferous Myriapoda from Illinois. Boston Society of Natural History, Memoir 4, 417-442.

SNODGRASS, R.E. 1938. Evolution of the Annelida, Onychophora, and Arthropoda. Smithonian Miscellaneous Collections 97(6), $1-159$.

Steiner, M. 2008. Taphonomy of Early Cambrian phosphatic fossil remains from South China. Erlanger Geologische Abhandlungen, Sonderband 6, 64-65.

Steiner, M., Li, G., Hu, S. \& Keupp, H. 2010. Soft-tissue preservation in small shelly faunas. Geological Society of America, Annual Meeting, Denver 42(5), 359.

Steiner, M., Zhu, M., Li, G., Qian, Y. \& Erdtmann, B.-D. 2004. New Early Cambrian bilaterian embryos and larvae from China. Geology 32(10), 833-836. DOI 10.1130/G20567.1

Van Roy, P., OrR, P.J., Botting, J.P., Muir, L.A., Vinther, J., Lefebvre, B., HariRi, K. El \& Briggs, D.E.G. 2010. Ordovician faunas of Burgess Shale type. Nature 465(7295), 215-218. DOI 10.1038/nature09038

VANDEL, A. 1949. Généralités composition de l'embranchement, 79-159. In Grassé, P.-P. (ed.) Traité de Zoologie. Volume VI. Masson et Cie, Paris. 
Vannier, J., Steiner, M., Renvoisé, E., Hu, S. \& Casanova, J.P. 2007. Early Cambrian origin of modern food webs: evidence from predator arrow worms. Proceedings of the Royal Society B, Biological Sciences 274(1610), 627-633.

DOI 10.1098/rspb.2006.3761

Waggoner, B.M. 1996. Phylogenetic hypotheses of the relationships of arthropods to Precambrian and Cambrian problematic fossil taxa. Systematic Biology 45(2), 190-222.

DOI 10.1093/sysbio/45.2.190

WalcotT, C.D. 1911. Cambrian geology and paleontology II, No. 5 - Middle Cambrian Annelids. Smithonian Miscellaneous Collections 57(5), 109-144.

Zhang, X. \& Aldridge, R.J. 2007. Development and diversification of trunk plates of the Lower Cambrian lobopodians.
Palaeontology 50, 401-415.

DOI 10.1111/j.1475-4983.2006.00634.x

Zhang, X. \& Pratt, B.R. 1996. Early Cambrian palaeoscolecid cuticles from Shaanxi, China. Journal of Paleontology 70(2), 275-279.

Zhao, Y., Yuan, J., Zhu, M., Yang, R., Guo, Q., Qian, Y., HuANG, Y. \& PAN, Y. 1999. A progress report on research on the early Middle Cambrian Kaili biota, Guizhou, PRC. Acta Palaeontologica Sinica, Supplement 38, 1-14.

Zhuravlev, A.Y. 2001. Biotic diversity and structure during the Neoproterozoic-Ordovician transition, 173-199. In Zhuravlev, A.Y. \& Riding, R. (eds) The Ecology of the Cambrian Radiation. Columbia University Press, New York. 